Toxicology.

\title{
EFFECTS OF SOME PLANT TOXINS ON FEEDING AND GROWTH RATE OF BARILIUS BENDELISIS (HAM.)
}

WPEYW NIEKTÓRYCH TOKSYN NA INTENSYWNOSC ŻEROWANIA I SZYBKOSC WZROSTU BARILIUS BENDELISIS (HAM.)

\author{
Department of Żoology \\ University of Garhwal, Sringgar
}

Tests conduced in the laboratory indicated that feeding rate in $\boldsymbol{B}$. bendelisis exposed with safe concentrations of Aesculus indica $\left(10 \mathrm{mg}^{-1}\right)$, Engelhardtia colebrookiana $\left(8 \mathrm{mg}^{-1}\right)$ Lyonia ovalifolia $\left(20 \mathrm{mg}^{-1}\right)$ and Zanthoxylem alatum $\left(2 \mathrm{mg}^{-1}\right)$ was reduced $37.3 \%, 39.0 \%, 17.12 \%, 47.3 \%$ (natural) and $33.5 \%, 48.0 \%, 16.3 \%, 51.5 \%$ (artificial) respectively as compared to the non toxicated fish. Growth analysis made at chronic level showed that initially, there was a decline in the weigth of fish due to less uptake of food and gradually the length was retariled. The study suhhested that since the active compounds of piscicidal plants, at safe concentration level affected the laste system of fishes. Consequently the rate of fedding was inhibited. The less feedinig and metabolic discorders found expression as a decline in the total growth of treated fish. It was evident that the pronciples of $A$. indica and $E$. colebrookiana were comparatively more growth inhibitors than $L$. avali ${ }^{\wedge}$ olia and Z. alatum.

\section{INTRODUCTION}

Feeding and growth being important parameters of fish bilogy and in fisheries mangement, have already been studied by numerous ichthyologists and the impacts of aquatic hazard process on fish are also assessed in recent 
past by Rosenthal and Alderdice (1976), Nagendran and Shakuntala (1979), Stebỏing (1981), Cairns (1984), Woltering (1984), Dave (1984), Dąbrowski (1984), Sarkar and Konar (1985), Arunachalam et al (1985) and others. But the information about the effects of plant toxins on feeding and growth of fish is scanty (Leonard, 1942; Marking, 1970; Loeb and Heg, 1970; Bhatt and Singh, 1985, 1988; Bhatt et al, 1987). However, because of poor feeding and slow experienced growth among the individuals of Barilius bendilisis, it was desirable to find out the fall in the both of the aforesaid parameters for the extracts of $A$. indica, E. colebrookiana, L. ovalifolia and Z $Z$. alatum.

\section{MATERIAL AND METHODS}

A. Collection of plants and extraction of their active proinciples.

Piscicidal plants viz Aesculus indica, Engelhardita colebrookiana, Lyonia ovalifolia and Zanthoxylem alatum oftenly used in Garhwal region were collected, air dried, powdered mechanically and extraced with $70 \%$ ethanol. The extracts then concentrated at reduced pressure were finally dried in vacum desicator. The residues were fractinated with Benzene, n-Butanol an chloroform - methanolw - water. The fractions of 'each plant so obtained have been subjected to isolate thair actiwe principles through coluum chromatography (Farswan, 1988). The isolated compounds were dried and $1 \%$ aquous solution of each compound was prepared to be used.

\section{B. Acclimatization of test fishes.}

Fry of $16-22 \mathrm{~mm}$ and $15-40 \mathrm{mg}$ and adukts of $79-210 \mathrm{~mm}$ and 35 to 239 $\mathrm{mg}$ (Barilius bendelisis) collected from the shallow pockets of nearby streams. They were acclimatized in the laboratory (water temp. $16-20^{\circ} \mathrm{C}, \mathrm{pH} 7.62, \mathrm{Do}$ 6.54 , free $\operatorname{Co} 23.5 \mathrm{pp}$. and experiments and were fed daily with the algae and rice cakes.

\section{Measurements on growth rate.}

Before starting experiments, the initial length and weigth was recorded on 40 individuals of each group. The same number of fry and adults were placed into the different (4.4) glass troughs inclui ng their respective control sets. Bioassays were conduced at the sublethal concentration levels of $A$. indica $\left(10 \mathrm{mg}^{-1}\right)$, E. colebrookiana $\left(8 \mathrm{mg}^{-1}\right)$, L. ovalifolia $\left(20 \mathrm{mg}^{-1}\right)$ and $Z$. alatum $\left(2 \mathrm{mg}^{-1}\right)$ and $Z$. alatum $\left(2 \mathrm{mg}^{-1}\right)$ for 32 daxs. The total growth of controlled and toxicated fishes was calculated at the termination of experiments using the least aquare method or straight line equation,

$$
\begin{aligned}
& \log Y=a+b \log x \\
& Y=\text { body weigth }
\end{aligned}
$$




$$
\begin{aligned}
& x=\text { body length } \\
& a \text { and } b=\text { parameters }
\end{aligned}
$$

D. Effect on food consumption;

The healthy adults of Barilius bandelisis acclimatized in the laboratory for 7 days, were devided in two groups and five flshes from each gropup were kept into the experimental troughs (4.4) including the control sets. Individuals of one set were provided the semidried algae and others were fed with rice cake. The food was put in patre dishes. The observations on each set of experiments were made for seven days and repeated twice. The balance food from the patre dishes was separated, dried and weighed. The rate of feeding was expressed in $\mathrm{mg}$ food (live fish) day (Maynard and Looshi, 1962; Arunachalam et al 1985).

\section{RESULTS AND DISCUSSION}

Abundant information is availvble in the deleteroius effects of the industrial, agricultural and domestic on the feedings and early growth of fish. However, the effects of piscicidal compounds of plants on fish have not so far been studied in detail. The results of the present study (Table 1) indicated that

Table 1

L c 50 Value $\left(\mathrm{mg}^{-1}\right)$ of plant principles to B. bendelisis (Ham)

\begin{tabular}{l|ccccc}
\hline \multirow{2}{*}{ Plant Principle } & \multicolumn{5}{c}{ Time interval (hrs) } \\
\cline { 2 - 6 } & 12 & 24 & 48 & 72 & 96 \\
\hline $\begin{array}{l}\text { Aesin based glycoside } \\
(\text { A. indica })\end{array}$ & 125.5 & 114.5 & 101.5 & 94.5 & 83.5 \\
\hline $\begin{array}{l}\text { Quercetine base glycoside } \\
(E . \text { colebrookiana) }\end{array}$ & 64.0 & 55.0 & 42.0 & 35.0 & 27.0 \\
\hline $\begin{array}{l}\text { Glycoside freesterol } \\
(\text { L. ovalifolia) }\end{array}$ & 183.0 & 167.0 & 145.0 & 130.0 & 115.0 \\
\hline $\begin{array}{l}\text { Bitter Principle } \\
(Z \text { altum })\end{array}$ & 12.1 & 10.2 & 9.0 & 7.0 & 5.5 \\
\hline
\end{tabular}

a small dose of $A$. indica $\left(100 \mathrm{mg}^{-1}\right), E$. colebrookiana $\left(40 \mathrm{mg}^{-1}\right)$, L. ovaliflia $\left(140 \mathrm{mg}^{-1}\right)$ and $Z$. alatum $\left(8 \mathrm{mg}^{-1}\right)$ was quite lethal to the fry and adults of $B$. benelisis.

Feeding being a major activitx of fish, many fold impacts of hazard on food cinsuption of various fish species have already been described by several workers in past. Bask and Konar (1977) reported thet Carp, Singhi and Tilapia reared in an insecticide (Dimethoete) showed a very low rate of feedind and 
they could, consume $10-19 \%$ abd $19-34 \%$ less amount of food in a comparision to the normal fishes. Similarly, regular decrease in the uptake of food was observed in T. mossambicá exposed with ammonium sulphate for a longer

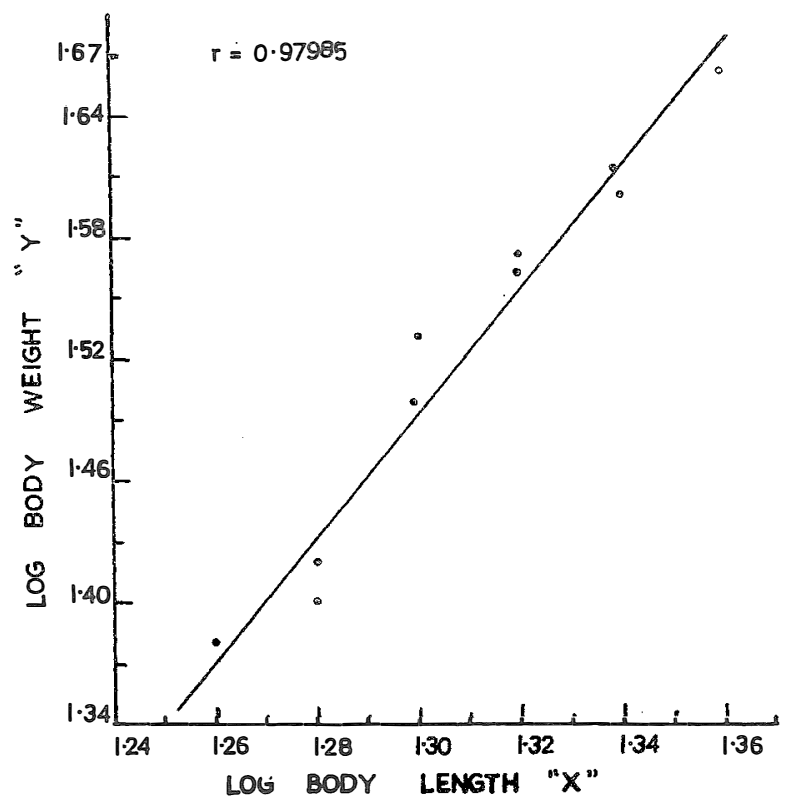

Fig. 1. Growth rate in normal fry of $B$. bendelisis

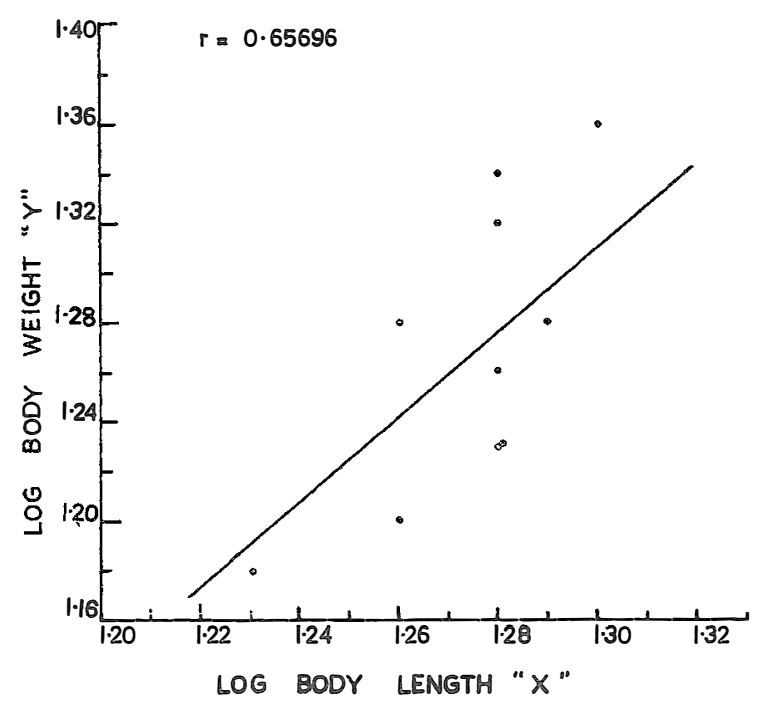

Fig 2. Growth rate in $A$. indica treated fry of $B$. bendelisis 
period (Sarkar and Konar, 1985). However, recently Marking et al (1984) illustarted that rainbow trout treated with eleven chemicalls, fed normally. Arunachalam et al (1985) found that $C$. puntatus put in 5 ppra carbaryl solution consumed $0.92 \mathrm{mg}$ dry food (live fish) day as compared to normal fishes those consumed $4.7 \mathrm{mg}$ dry food (live fish) dar.

Such contradictory findings of the earlier workers need to be explained in terns of aeveral factors. The food cinspuption certainly depended upon the nature and mode of action of the toxicant, dietary habit and sensitivity of a particular fish species, and length of the esposure. During the tenure of present siudiy (Fig. 6,7) B. Bendelisis exposed with safe concentrations of $A$. indica (10 $\left.\mathrm{mg}^{-1}\right) \mathbb{E}$. colebrookiana $\left(8 \mathrm{mg}^{-1}\right) \mathbb{L}$. ovalifolia $\left(20 \mathrm{mg}^{-1}\right)$ and $\mathbb{Z}$. alatum $\left(2 \mathrm{mg}^{-1}\right)$ consumed $37.33 \%, 39.9 \%, 17.16 \%, 47.33 \%$ (naturall) and $33.53 \%, 48.00 \%, 16.33 \%, 51.5 \%$ (artificial) respectivelly in contrast to the toxicated fish. At this level fish neither expered nor presented any visible response to the poisons but feeding was significantly inhibited. Fishes esposed below these concentrations fed in an usual manner, whille those treated with higher doses sould not survive.

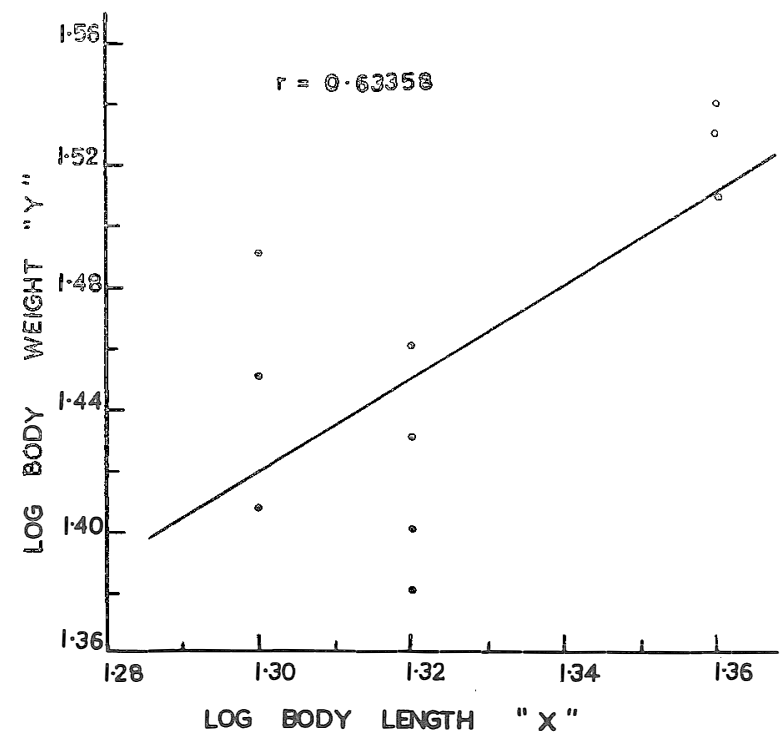

Fig. 3. Growth rate in $\mathbb{E}$. colebrookiana treated fry of $\mathbb{B}$. bendelisis

Since vision (Bhatt and Singh, 1980), teaste (Atema, 1971) and olfaction (Kapoor and Ojha, 1973) play an inoportant and leading role in the feedin' of osth, the most probable consequence of their degradation moght have adverselly influenced the rate of food uptake in fish. B. bendelisis besides sight, also feed with mouth taste (Badola and Singh, 1980). Bardach et all (1965) have stated 


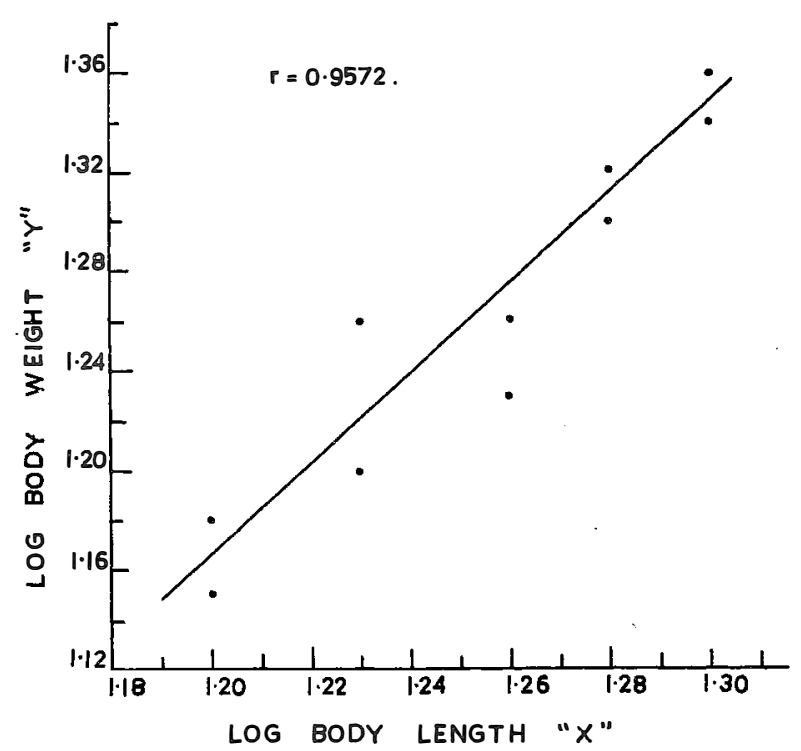

Fig. 4. Growth ratw in $\mathbb{L}$. ovalifolia treated fry of $B$. bendelisis

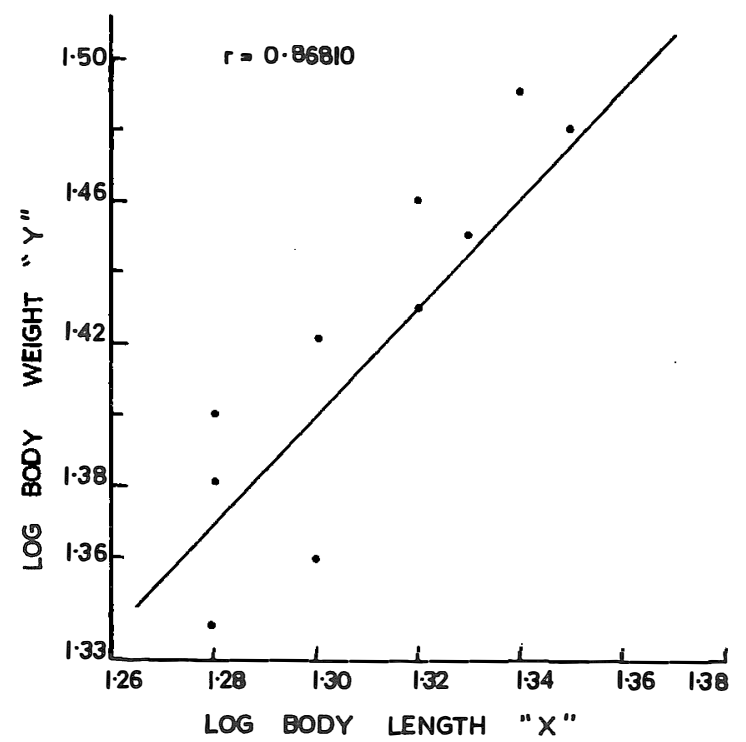

Fig. 5. Growth rate in $\mathbb{Z}$. alatum treated fry of $B$. bendelisis

that the rate of food consumption in a detergent treated fish was degraded due to the degeneration of taste buds. Since these plant toxins affected the receptor of fish (Bhatt and Singh, 1985), certainly they inhibited the food finding ability of fish. 
Sprague $(1970,1976)$ opined thet growth should routinely be measured in all chronic experiments and he considered it one of the 75 Critaria, as a basis for the hazard evaluation. Rosenthal and Alderdice (1976) reviewed that the primary (hidden) effects of certain toxicants on the early development stages come as the secondary quantifiable effects whose consequences later on, may find expression as tertiary effects. Many toxicants are known to have the deleterious effects on the survival, growth and reproduction of fish (Jonson, 1968; Epa Ram 1971; Mckim et al 19788 Manoharan and Subbiah, 1982; Sarkar and $\mathbb{K}$ onar, 1985; Mani and $\mathbb{K}$ onar, 1985 and Arunachalano et al 1985).

Thingaran (1982) in his book "Fish and Fisheries of India", reported that a rabge of $12-28^{\circ} \mathrm{C}$ temperature, $5-10.5$ ppm dissolve oxygen, $7.45-8.3 \mathrm{pH}$ and $72-212$ ppm alkalinty is suitable for the normal growth of fish. During the course of present study, therefore, the physio-chenaical parameters of the test water were naintained with in the above prescribed range in order to avoid their ill effects on fish. Hence, the fry of $B$. bendelisis exposed with the concentration, $2 \mathrm{mg}^{-1}, 8 \mathrm{mg}^{-1}, 10 \mathrm{mg}^{-1}$ and $20 \mathrm{mg}^{-1}$ of $\mathbb{Z}$. alatum, $\mathbb{E}$. Cilebrookiana, A. indica and $\mathbb{L}$. ovalifolia respectively for 32 days, showed a remarkable decline in their growth (Fig. I). According to Rosenthal and

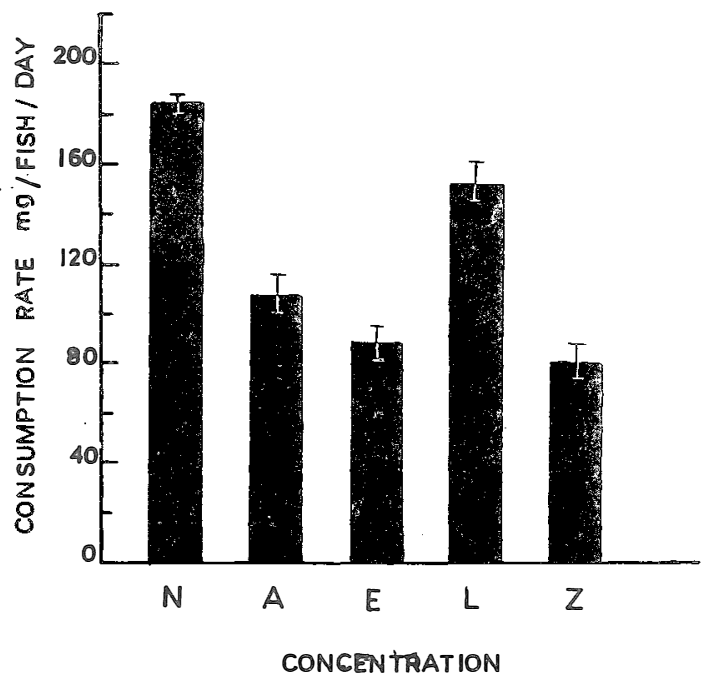

Fig. 6. Mean of food (artificial) consumption rate in B. bendelisis at different exposures $\mathbb{N}$ - Fry not treated (normal fry); $\mathbb{A}$ - Aesculus indica; $\mathbb{E}$ - Engelhardtia colebrookiana: $\mathbb{L}$ - Lyonia ovalifolia; $\mathbb{Z}-$ Zanthoxylem alatum

Alderdice (1976) the toxicated fish become more susceptible to be damaged and diseased that might be due to less consumption of food and indequate conversion efficiency in such unviduals (Larsson et al 1985; Leduc, 1978 and Rowe et al 1983 b). The molicular basis of these finding later on, are interpreted 
by Stebbing (1981, 1982), Taylor (1985) and Lewis and Weber (1985). Who have stated that the toxicant induced stimulations (hormesis) influence the interation of fish towards the food particle. This condition evidently inhibited the development of fish. Thus inefficiency to compete the suitable habitat, delayed maturation and reproduction, abnormal behaviour and physiological disorders are all possible out breaks of reduced growth, However, the toxic principlas of A. indica, $\mathbb{E}$. colebrookiana, $\mathbb{L}$. ovalifolia and $\mathbb{Z}$. alatum affected the feedings, respiration and sensory mechanism in B. bendelisis (Bhatt and Singh 1985 , 1988). Such alterations might lhave disturbed te metabolic pathways in the fish.

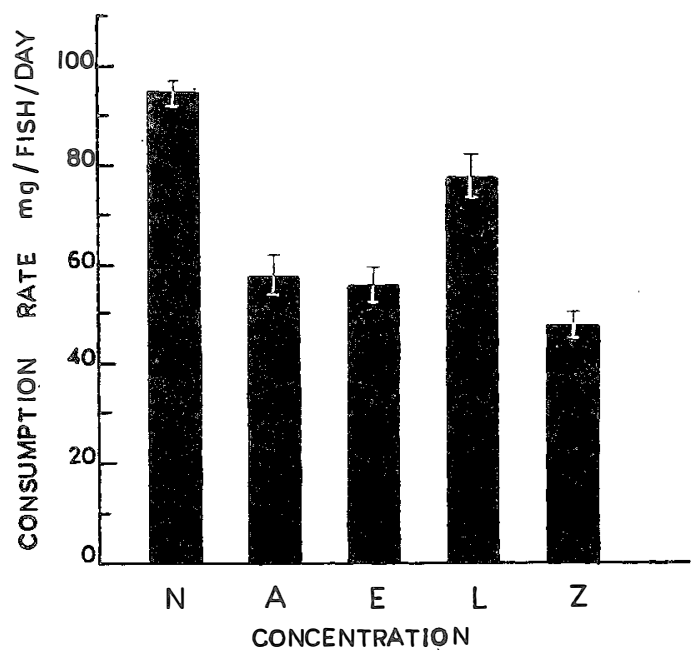

Fig. 7. Mean of food (natural) consumption rate in B. bendelisis at different exposures N - Fry not trested (normal fry); A - Aesculus indica; E - Engelhardtia colebrookiana; $\mathbb{L}-\mathbb{L}$ yonia ovalifolia; $\mathbb{Z}-\mathbb{Z}$ anthoxylem alatum

Primarily there appeared a fall in the weight which gradually followed by the decline in the length (Fig. 4, 5, 6, 7). Thus the present findings support the study of Webb and Brett (1973) and Manoharan and Subbialh (1982), who have expressed that pesticides, in general act as Metabolic stressors and centainly may decline the conversion efficiency and growth of fish. Present study also showed that the inhibition in the growth was more among the individuals exposed with $E$. colebrookiana $(\mathrm{r}=0.633$ and $A$. indica $(\mathrm{r}=0.659)$ than those treated with $Z$. alatum $(r=0.868)$ and $L$. ovalifolia $(r=0.957)$. 


\section{AKNOWLEDGEMENTS}

Authers sre grateful to the Department of Science and Technology, New Dellai, for fimancial support. Gratful thanks are also due to Professor $\mathbb{H}$. $\mathbb{R}$. Singh, Head of Zoology Department for laboratory facilities.

\section{REFERENCES}

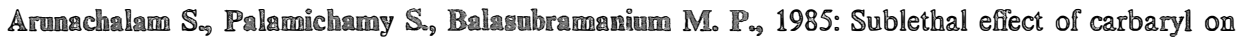
food utilization and oxygen consumption in the air breaching fish $\mathbb{C}$. puntatus (Block.) J. Exp. Biol. 6 (4): 279 - 286.

Ateriman $\mathbb{J}_{a}$ 1971: Structure and functions of the sense of taste in the cat fish (Ictalurus natalis). Brain. Behav. and Evolog A: 273-294.

Badola S. $\mathbb{P}_{\circ}$ Singh $H_{0} \mathbb{R}_{\circ}$ 1980: Food and feeding habits of fishes of genera Tor Puntius and Barilius. Proc. Indi. Nat. Sci. Advo, B 46 (1): $58-62$.

Bardech Jo $\mathbb{E}_{\text {o, }}$ Fujixs $\mathbb{M}_{\text {og }}$ Holl $\mathbb{A}_{\text {og }}$ 1965: Detergents effect on the chemical senses of the fish Ictalurus natalis (ie. saur). Science., 148: 1605-1607.

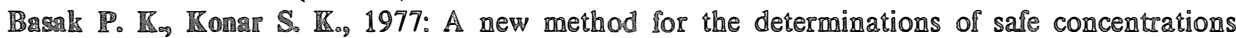
of "insecticides, to project fishes. Ind. J. Env. Hlth; 19: 283292.

Bhatt Jo $\mathbb{P}_{\text {og }}$ Singh $\mathbb{H}_{0} \mathbb{R}_{0,}$ 1980: Brain pattern in P. chilinoides (Mcclelland). Bioresrch, 4 (2).

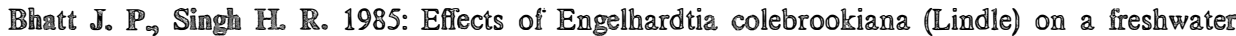
teleost (Barilius bendelisis Ham.). Science and Culture, 51 (4) 132-133.

Bhatt J. $\mathbb{P}_{\text {og }}$ Singh $\mathbb{H} . \mathbb{R}_{\text {og }}$ 1988: Experimental studies on the lethal toxicity of high altitude piscicidal plante to coldwater teleosr of Garhwall Life Science Adv. (in press).

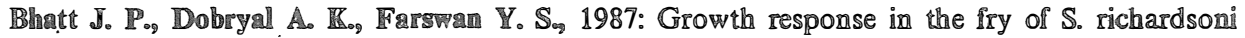
(Gry) to plant toxins. J. Env. Biol., (2): $207-215$.

Cairns J. Jro, 1984: Multispecies toxicity testing. Envirol. Toxicol and chemistry., 3: 1 -3.

Dąbrowslisi $\mathbb{R}_{\text {og }}$ 1984: The feedings of fish larval, present "State of the art perspectives". Repro. Nutri. Devo, 24: 807 - 833.

Dave $\mathbb{G}_{0}$ 1984: Effects of $\mathrm{pH}$ on pentachlorophenol toricity to embryo and larval of Zebra fish (Brachydanio rerio). Bull.Env. Contam. Toxical, 33: 621-630.

Epa Ram, 1971: Effect of Chemicals on aquatic life, water quality criteria databook, Water poll. Cent. Res. Series, Washington., 3: 326-239.

Farswan Y. So, 1988: Effect of some plant toxicants on hill stream fishes of Garhwal region Ph. D. Thesis. Garhwal Universiry, Srinagar Garhwal, India.

Johnson D. W., 1968: Pesticides and fishes, a review of selected literature. Ztrans. Ame. Fish. Soc. 97: $398-424$.

Jhingran V. Go, 1982: "Fish and Fisheries of India" Hundustan Publ. Corpo. New Dellai, II ed.

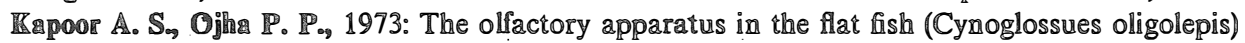
Trans. Ame. Micro-Soc. 92 (3): 298 - 304.

Larsson Aog Haux $\mathbb{C}_{\text {o, }}$ Sjobeck M. Lon 1985: Fish physiology and naetal Pollution: Results and experiences from Laboratory and field studies. Estoxicol and Environ. Safety, 9: 250-281.

Leduc $G_{\infty}$ 1978: Deleterious effect of cyanide on early life stage of atlantic salmon. J. Fish. Res. Bd. C2n: $166-174$.

Leob $H_{0} \mathbb{A}_{\circ}$ and $\mathbb{H e g} \mathbb{R}_{0} \mathbb{E}_{o}$ 1970: Time dependent changes in toxicity of Rotenone dispersions to trout. Toxicol. Appl. Pharmacol 17: 605-614.

Leomard J.Wo, 1970: Notes on the use of Derris as a fish poison. Anerican Fish. Siciety, 68: $269-280$. 


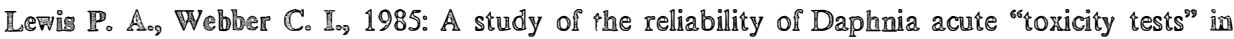
$\mathbb{R}$. D. Cardwell, $\mathbb{R}$. Pury and $\mathbb{R}$. C. Bahner (eds), Aquatic toxicol. and hazard Assessment: Seventh symposinn AS TM STP 854 American Society for Testing and material Philadelphia: $73-86$.

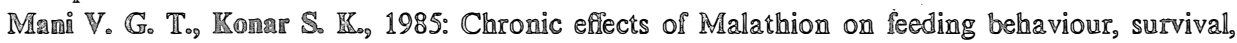
growth and reproduction of fish. Enviromment and Ecoll, 3 (3): $348-350$.

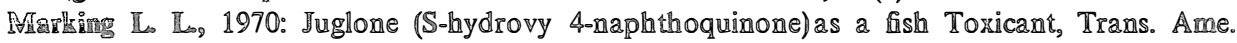
Fish Soc. 3: 510-514.

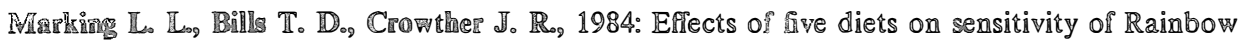
trout to eleven chemicals. Progressive Fish-Culturist., 46: $1-5$.

Mckin $\mathbb{J}_{0} \mathbb{M}_{\circ}$, Eatom $\mathbb{J}_{0} \mathbb{G}_{\circ}$ Holcombe $\mathbb{P}_{\circ}$ 1978: Metal toxicity to embryos and larval of eight species of freshwater fislo II, Coppe. Bull. Env. Contam. Toxicol., 19: 608 - 616.

Mamoharm $\mathbb{T}_{\text {o, }}$ Subbian $\mathbb{G}_{0} \mathbb{N}_{\circ}$, 1982: Toxic and sublethal effects of endosulfan on $\mathbb{B}$. Stioma (Pisces: Cyprimidae). Proc. Indian Acad. Sci. (Animal Science). 11: 523 - 532.

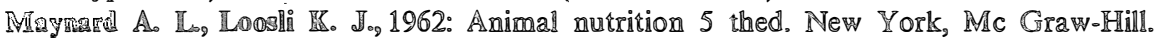

Nagendrain Ro, Shalsamtal $\mathbb{L}_{\circ}$ 1979: Effects of sublethal concentrations of sodium pentachlorophenate on the exophysiology of Puntius ticto (Ham). Ind. Exp. Biol., 17: 270-273.

Rosmethal $\mathbb{H}_{\text {og }}$ Alderdice $\mathbb{D}_{\text {. }} \mathbb{F}_{\circ}$ 1976: Sublethal effects of envirommental stressors, Natural and Pollutional on marine fish eggs an larval. J. Fish. Res. Bd. Can. 33: 1939-1945.

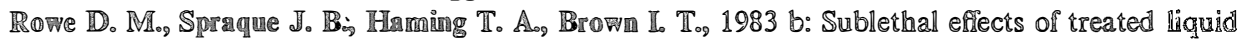
effluent from a petroleum refinery II rowth of Rainbow trout. Aquat. Toxicol. 3: 161-169.

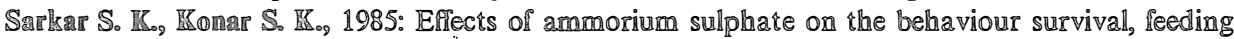
grow th and reproduction of fish. Env. Ecol. 3 (3): $312-315$.

Sprague J. Bo, 1970: Measurment of pollutant toxicity to fish, 2-Utilizarion and applying bioassay results. Water Research, 4: 3-22.

Sprague $\mathbb{J}_{0} \mathbb{B}_{3}, 1976$ : Current status of sublethal tests of pollulants on aquatic organisms, J. Fish. Res. Bd. Can. 33: $1988-1992$.

Stebbing A. R. D., 1981: Hormesis stimulation of colony growith in Campanularia flexuosa (hydrozoa) by copper, cadmium and other toxicants. Aquatic Toxicol. 1: 227-238.

Stebbing A. R。 Do, 1982: Hormesis-the stimulation of growth by low levels of inhibitors. Science of the Total Environment., 22: 213 - 234 .

Tæylor M. I. 1985: Effect of diet on the sensitivity of Daphnia magna to limear alkylbenzene sulfonate in $\mathbb{R} . \mathbb{D}$. Cardwell, $\mathbb{R}$. Purdy and $\mathbb{R}$. C. Bahner (eds) Aquat. Toxicol. and harard Assessment: $53-72$

Webb P. Whand Brett J. Ro, 1973: Effects of sublethal concentrations of sodium pentachlorophenate on growth rate, food conversion efficiency and swimming performance in under yearling sockeye salmon (O. nerca). J. Fish. Res. Bd. Can. 30: $499-507$.

Woltering D. Mo, 1984: The growth response in fish chronic and early life stage toxicity tests: A critical review. Aquate. Toxicol. 5: 1-21. 
Y. S. Farswan, J. P. Bhatt, S. N. Bahuguna

WPLYW NIEKTOKRYCH TOKSYN ROSLINNYCH NA INTENSYWNOSC ZEROWANIA I SZYBKOSC WZROSTU BARILIUS BENDELISIS (Ham.)

\section{STRESZCZENIE}

Przeprowadzone w warunkach laboratoryjuych badania wylkazaly spadel intensywności żerowania B. bendelisis pod wplywen uznanych za bezpieczne stęėen toksyn Aesculus indica (10 $\left.\mathrm{mg}^{-1}\right)$, Engelhardtia colebrookians $\left(8 \mathrm{mg}^{-1}\right.$, Lyonia ovalifolis $\left(20 \mathrm{mg}^{-1}\right)$ i Zanthoxylem alatum $\left(2 \operatorname{mog} g^{-1}\right)$.

Spadels ter wymosi odpowiedmio $37,3 \%, 39,0 \%, 17,2 \%$ i $47,3 \%$ (dla pasz naturalnych) oraz - $33,5 \%, 48,0 \%, 16,3 \%$ i $51,5 \%$ (dla pasz sztucznych w porównaniu z próbą kontrolna

Analiza wzrostu ryb wylcazała poczatkowy spadek ich nasy ciała wynilkający $z$ maiejszego pobierania pokarmu, przy jednoczesnym, stopniowym hamowaniu przyrostu ollugości. Wymiki badań sugerują, że alktywne zwiazki wytwarzane przez rośliny wodne w bezpiecznych stężeniach, oddziaływaly na ryby, hamując intensywmość żerowania. Mniejsze pobieranie polsarnu i zaburzenia metaboliznu zmalazły wyraz w spadru wzrosiu doświadczalnych ryb. Jednocześnie zwiazki wytwarzane przez A. indica i $\mathbb{E}$. colebrookiana hamowaly wzrost ryb w więrszyn stopniu niz $\mathbb{L}$. ovalifolis i $\mathbb{Z}$. alatum.

Authors' addresses:

Received: 1989.03 .20

Mr Y. S. Farswan

Dr. J. P. Bhatt

Dr. S. N. Bahugura

Deoartionent of Zoology, University of Garhwal

Srimagar Garwal . (UP) prom-246174 INDIA 